\title{
AN ANALYSIS OF PERSONAL AND COLLECTIVE TRAUMA IN \\ KHALED HOSSEINI'S NOVEL SEA PRAYER
}

\author{
Laila Shoukat \\ lailakhannn9@gmail.com \\ National University of Modern Languages Peshawar Campus, Pakistan \\ Sanah Waheed \\ sanahwaheed0099@gmail.com \\ National University of Modern Languages Peshawar Campus, Pakistan \\ Khushnood Arshad \\ khushnoodarshad566@gmail.com \\ National University of Modern Languages Peshawar Campus, Pakistan
}

\begin{abstract}
This research study is an attempt to explore the literary text of "Sea Prayer" written by Khaled Hosseini with the perspective of trauma study that includes personal trauma model of Cathy Caruth and collective trauma model of Kia Erikson. The theoretical framework focuses on both i.e., Caruth (1996) personal trauma discussed in "Unclaimed Experience: trauma, narrative and history" and Erikson (1991) collective trauma discussed in "Notes on Trauma and Community". This research study examines the elements of personal trauma of the Narrator's character through flashbacks, timelessness and unspeakably. On the other hand, the elements of collective trauma are also investigated that is breakage of the communal bond, distrust in future, the mood of fear and depression on the collective level. In addition, the method used is qualitative analysis. Through the aforementioned elements, the researcher has discussed the collective trauma of the Syrian community as a whole.
\end{abstract}

Keywords: Trauma, Sea Prayer, textual analysis, Cathy Caruth

\section{INTRODUCTION}

Literature is the form of art, which

society from ancient civilization to depicts every aspect of life in literary pieces. Literature gives the insight of society, culture and the world around us. Through literature, one can explore the modern. It is not just a historical or cultural artefact. Rather, it opens up a new world of experience for readers. Along with that literature also interlinks with the study of 
the mind. By reading such literary pieces one can find elements of psychology like how traumatic experiences can affect the life of an individual. Trauma studies can be taken as a counterpart, which reflects the causing factors and the disturbed psyches of characters in the text. Likewise, literary trauma theory is developed to apprehend the aforementioned features of literature.

\section{a) Trauma Theory}

Lately, readers can find the abundant usage of the concept of trauma in literary pieces. We are living in the age, were due to living under atrocious circumstances many of the people are suffering from traumas.

Trauma at first was mainly referred to as an injury on the body. However, later on, its meaning shifted to other terms especially in the field of medicine, psychiatry and in literature as well.

Similarly, trauma studies were first originated in the 1990s by Sigmund Freud. While working on this, he introduced the model of psychoanalysis. This model is mainly based on the personality of an individual. Regarding trauma, many developments were followed afterwards. Caruth (1996) in her book Unclaimed Experience: Trauma, narrative and history have introduced the literary trauma theory.
She has explained trauma as repetitious, timeless and unspeakable. She describes personal trauma as repetitious because it reoccurs in flashbacks in the mind of the character. Moreover, she is of the view that personal trauma is timeless because it makes a person stuck at a point. In this way, a person starts mingling both his past and present. On the other hand, she described personal trauma as unspeakable because it causes impairment to both consciousness and language. Due to trauma, the person is not conscious of his presence as he is stuck in the past and cannot express his feelings to others.

Trauma theory on one side represents the single psyche while on the other hand; it demonstrates the collective trauma of a community or society as a whole.

Similarly, collective trauma is explained by Erikson (1991) in his article "Notes on Trauma and Community" published in the journal. According to him, trauma is defined as a blow which creates disturbed feelings and behaviour. Moreover, he depicts the traumatized communities as a group that act as the collective sufferers from trauma. Likewise, Erikson is of the opinion that collective trauma destroys the basic fibre of society. Similarly, he says it creates distrust in the 
future and presents fear and depression on the collective level. He is of the view that Collective trauma is caused by different factors like ruthless colonization, war, natural disasters, rights deficit, worse socio-political conditions and natural disasters.

b) Khaled Hosseini and Sea Prayer Children literature was developed in the 16th and 17th century. However, the purpose of writing literary pieces for children has been changing since ages. Firstly, it was used for didacticism and moralism. Then, its purpose inclined towards fairy tales and fables. However, in the $19^{\text {th }}$ century, it mostly portrayed the innocence of children. While the development of trauma in children literature began in the 1990's.

Children literature includes fairy tales, fables and picture books. Picture books as a genre, demonstrate the emotional and fictional lives of children. Picture books are introduced to equip the mindset of children through visual powers, to make them understand the political and social conditions. For example, Khaled Hosseini's book Sea Prayer is both a picture and literary book which talks about the traumatic experiences of a refugee kid.

Khaled Hosseini is an Afghan American novelist and physician, born on
March 4, 1965, in Kabul. His family moved to the United States before the Soviet invasion in Afghanistan. Moreover, he is the author of A Kite Runner, Thousand Splendid Suns, The Mountains Echoed and Sea Prayer. In his writings, he has discussed the vulnerability of people particularly Afghanis, living under the harsh circumstances of War. He has narrated the ordeal of people living in wartorn parts of the world. Also, he seems to advocate the rights of females who are deprived of their basic rights in the patriarchal society of Pashtuns. Similarly, he talks about the refugee crisis in his books. In this way, one can also find survivor's guilt implicitly interwoven by him in novels. He feels pity for those who bear the burden of war. He in order to express his viewpoint mostly makes use of two devices symbolism and imagery. He uses such a compelling tone that readers get deeply involved in the text and can feel pity for the Afghanis. As well as, the diction he uses in his novels is easily comprehendible.

Sea Prayer is a short book written by Khaled Hosseini in 2018 with regard to the current refugee crisis. It is written in the form of a letter from the narrator (father) to his son Marwan during the harrowing journey of their life when they left their land due to the horrendous war. This text is 
basically inspired by the heart-wrenching story of a three-year-old Syrian refugee, Alan Kurdi, who got drowned in the Mediterranean Sea in 2015, in his doleful journey, trying to reach Europe.

The story opens up with the nostalgia of the narrator when he recounts the memories of the peaceful days before war broke out in Syria. He tells his son Marwan about his own childhood that how he and his uncle used to spread their mattress on their grandfather's farmhouse roof. Then, the narrator visualizes the scenario of the early morning of his childhood, how he woke in the morning with the tossing of olive trees in the breeze and clanking of pots and bleating of grandmother's goat. Moreover, the narrator also wants his son to remember those golden days too when his mother walked him in the fields, blooming with wildflowers. Also, the old city was full of hustle and bustle. Similarly, there were worship places for every community. Further, the narrator laments about how scary memories of Marwan are that all he can remember is bombs, starvation and

\section{REVIEW OF RELATED LITERATURES}

The research article "To Have Memories or Not- The Buried Giant bloodshed. Besides these, the narrator also demonstrates their difficult voyage to safe havens along with other people and expresses his fear of being unwelcomed on their lands. Moreover, it gives the images of their lives before the brutal war in Syria and then it pictures the destructed view of Syria after the horrible war broke out.

Throughout the story, one can find the cycle of traumatic experiences. Both the narrator and his son Marwan are the voice of refugees and they depict the torments as being a refugee, one can face. Through the application of trauma theory, the researcher has deployed the personal and collective traumas through the models of Caruth (1996) and Erikson (1991).

\section{Objectives of the Study}

In general, the purpose of this study is summarized in two parts as follows:

- To analyze the personal trauma of the narrator in the literary text Sea Prayer by Khaled Hosseini,

To highlight the ways in which literary text Sea Prayer by Khaled Hosseini shows the collective trauma of Syrian community. 
main characters, Axl and Beatrice, and suggests how their repressed memories strike in their mind repeatedly in the novel The Buried Gigantic penned by Kazuo Ishiguro.

The research article "Analyzing Delayed Traumatic Reactions in Stephen King's Gerald's Game: A Freudian Perspective" conducted by Yadav and Mishra (2020). It highlights the personal trauma of how it becomes a hindrance in the way of one's progress as a human, a memory from past keeps coming back and shackled the person. The researcher has depicted Jessica as a traumatized character.

Another research article "War Trauma, Collective Memory, and Cultural Production in Conflict Zones: Kashmir in focus" conducted by Hanif and Ullah (2018), explores the collective trauma of Kashmir community in Mirza Waheed's The Collaborator through the Kia Erikson's collective trauma theory concept. Researchers have elaborated the collective trauma on the oppressed Kashmiri community through the ruthless war that they have been experiencing since decades. Impact on psyches and the basic fibre of society which are destroyed due to worsening socio-political situations are the major focus of collective trauma in this article.

Similarly, research study "Art as a narrative: Recounting Traumas through Literature", conducted by Abubaker, S (2017) states how trauma theory performs a vital role in literature. In the same manner, she concludes that idea of trauma lays both in personal and collective aspects such as rape, domestic violence, child abuse, poverty, disease outbreaks, pandemics, wars, calamity, natural disasters and genocides etc. becomes the causing factors of trauma that can be represented via literary pieces.

Similarly, Dodhy (2017) has discussed the trauma theory with the aspect of personal trauma through the element of anxiety and memory in the research study "Traumatic Memory and Legacy of Anxiety Yvonne Vera's Under the Tongue". This researcher paper explores the disturbed psyche and social setup of the sexual assault victim. Through the application of trauma theory, the researcher explains how the heinous and indelible incident of her life is affecting her.

"The Trauma of the Routine: Lessons on Cultural Trauma from the Emmett Till Verdict" is another research study conducted by Willig (2016), that 
discusses two aspects of trauma theory. The researcher demonstrates the cultural trauma of the African community through the black characters. Researcher narrates the effects of cultural trauma on the public in the form of rage after the acquittal of murderers by police. As well as, highlights the deep chasm between two communities, i-e, whites and blacks. In the same article, he also highlights Kia Erikson's collective trauma through the breakage of the basic fibre of American society.

Another research study "Writing Trauma: Magical Realism and the Traumatic Imagination", conducted by Arva and Roland (2015). They are of the view that narrative strategy is a viable medium for the depiction of historical trauma. Moreover, they suggest even writings of modern era depicts the traumas of former ages. For this, they provide the instances via historical traumas from September 11, 2001, the transgenerational of the decedents of Holocaust survivor. As

\section{METHODS}

Trauma theory is a literary theory which discusses the disturbed psyche and it's causing factors. The researcher has deployed personal and collective trauma through this theory. well as, they provide the glimpses of the trauma of displacement of Turkish peasantry.

Nojvane (2012), in his research article "Trauma, (Mis) Perception and Memory in Uwem Akpan's Fattening to Gabon" discusses the personal trauma of character 'kpee' that how flashbacks of his past effects his present. He concluded that personal trauma is an indelible mark on the psyche of an individual and how does it affect his outlook towards life. Besides this, in the same research paper, he gives a slight view of collective trauma by highlighting the shambolic socio-economic situations of Africa through the character of 'kpee' being sold by his father.

Research Study "Green Knowe: An English Ark" conducted by Emerson (2008) has discussed trauma theory with regard to personal trauma. The researcher has explored memory and time of characters which keeps refreshing the repressed past events in their mind.

Trauma studies were first introduced in 1990's by Sigmund Freud while treating a hysteric patient. He, later on, gave the psychoanalytic model. This model is considered the model of 
personality. Besides, he is of the view that trauma cannot be represented.

\section{Cathy Caruth's Trauma Model}

Caruth (1996) in her book Unclaimed Experience: Trauma, narrative and history have introduced the literary trauma theory and three aspects of personal trauma which are repetitious, timeless, and unspeakable. She states that trauma is repetitious because it reoccurs in the mind of a person through flashbacks. On the other hand, she claims that it is timeless. It is timeless in the sense that it makes a person stuck in his past. No matter, where he is present how far he is from that place of where he had experienced that event of trauma. It will dwell in his mind. The person will seem kind of mingling both times i-e, present and past. Similarly, her third point is regarding conscious and language that trauma is unspeakable. She is of the view that due to trauma destabilizes both language and consciousness.

Aforementioned points of Cathy Caruth's personal trauma model are conducted on the text of Sea Prayer, where the researcher has analyzed it through the character of the Marwan's father, who is the narrator of the story.

\section{a) Kia Erikson Collective Trauma}

Erikson (1991) in his article Notes on Trauma and Community published in the journal has explained the collective trauma. He states trauma is not a naturally occurring event, rather it is constructed by horrible events, which leave an indelible mark on the minds. According to him, trauma is defined as a blow which creates disturbed feelings and behaviour. Moreover, he depicts the traumatized communities as a group that act as the collective sufferers from trauma. Likewise, Erikson is of the opinion that collective trauma destroys the basic fibre of society. Similarly, he says it creates distrust in the future and presents fear and depression on the collective level. He is of the view that collective trauma is caused by different factors like ruthless colonization, war, natural disasters, rights deficit, worse socio-political conditions and natural disasters.

In this research study, through the characters of Marwan and the narrator (his father), collective trauma is explained under the discussion of Erikson's collective trauma model. 
The research is both qualitative and quantitative in nature. Quantitative in a sense that it includes statistical data in the form of tables. Moreover, it talks about the different themes of the novella, which shows the qualitative nature of the research.

\section{RESULTS AND DISCUSSION}

Approximately, half of the population of Syria has been displaced since the horrendous war broke out. People are still suffering under harsh circumstances. The refugee crisis has become the talk of the town lately. They are considered those beings, who are facing each sort of dangers on the face of the earth. Many of them lost their dear ones intense and severe aerial bombings, while others went missing in their harrowing journeys in search of better opportunities and safe destination. However, their torments do not just end here; rather, most of the countries are banning their borders for them by labelling them as terrorists. On the other hand, they are also confronting the issues of impoverishment, scarcity of food, taking shelter in slums and rights deficit. The refugee crisis is a grave issue which is escalating day by day.

In addition, out of all, refugees are those who are more exposed to traumatic experiences. Similarly, most of the works could be found written upon the refugee crisis and the psychological trauma, experiencing by Syrian community.

Likewise, Sea Prayer as a literary text also deals with the traumatic experiences one can experience as being a refugee.

Moreover, Khaled Hosseini has tactfully interwoven the causing factors and the impacts of the psychological trauma in this text.

This text is basically inspired by the heart-wrenching story of a three years old Syrian refugee, Alan Kurdi, who drowned in the Mediterranean Sea in 2015, in his doleful journey, trying to reach Europe.

This research study has deployed the glimpses of trauma both on the personal and collective level through the references from the text of Sea Prayer.

\section{a) Personal Trauma}

According to Caruth (1996), trauma occurs repeatedly in the form of flashbacks. This concept can be understood by the following lines from the text, in which the 
narrator says "The skies spitting bombs.... Burials.” (Hosseini, 2018, p.18)

These lines are uttered by the narrator when he along with his wife and son (Marwan), leaves his country in search of safe land. Though, he is travelling in a ship along with other people. However, his mind has taken him away from being present over there. At that point, he travels back to past, when he was present there (Syria) during the brutal war, where he witnessed ruthless and severe aerial bombings and piles of corpses under the rubble of buildings.

From the text, it could be seen that the narrator of the story is unable to efface the horrible memories of his past, which repeatedly haunts him in his presence.

Likewise, through another textual reference "First came the protest, then the Siege" (Hosseini, 2018, p.16) elaborates the flashback as well.

Again, the narrator is witnessed as being taken away by his thoughts of the past. Flashbacks of his past are found in the text, which is haunting him again and again. Though, he is not under such circumstances anymore. He flees from his country along with his family in order to find a better place to live.

One can evaluate the timeless relationship of the narrator's past. $\mathrm{He}$ is found stuck in his past and kind of mingling both past and present in his mind, particularly, when he rekindles his traumatic flashbacks in the start and middle of the text. Firstly, the narrator seems nostalgic as he laments about the old days when everything was at peace, and markets were full of hustle and bustle. However, then one can see a sudden shift in his memories from bright to dark times. There his flashbacks give readers the picture of his past when he along with his family was living under deplorable conditions. Though at that time he is somewhere in the middle of the sea, travelling in search of safe land but he finds stuck in his past. Instead of gearing himself up for upcoming situations, he is reviving his past in his mind. For instance, the following lines "My dear Marwan, in the long summers of childhood.... Of your grandfather's farmhouse outside of Homs" (Hosseini, 2018, p.1) provides such glimpses.

This is the very opening where the narrator seems nostalgic where he is talking to his son Marwan about the golden times of past that how pleasant everything was. He is lost in the days of his past memories when Syria was a war-free peaceful country.

Then, in the middle of the text, the reader can find him stood aghast in the bitter memories of his past. This describes the 
timeless relationship of his flashbacks. For instance, "You know a bomb crater.... A swimming hole." (Hosseini, 2018, p.23)

Here, the lives of the narrator family have been depicted that how in the war-torn country their lives were messed up. Marwan, instead of playing with toys, he was having the residue of missiles and bombs in his hands.

Moreover, in this literary text, researchers have also highlighted another aspect regarding personal trauma; model of unspeakably. "Extreme experience destabilizes both language and consciousness" (Caruth, 1996). This aspect states that a traumatic person is unable to give an expression of his thoughts like in the scene when his wife whispers in his ear that surely they will get assistance from others. At least, they will show sympathy towards our son. For instance, "They would say kinder things, surely.”(Hosseini, 2018, p.30)

In the above-mentioned lines, he does not express his grief and thoughts like he was expressing before "We are the unwelcome." (Hosseini, 2018, p. 29)

Rather, he shifts towards his son and started discerning him keenly. He did not tell her that no one over there is interested in helping the unfortunate refugees like them. But instead of this thing, the narrator uttered something else to his son "Hold my hand, nothing bad will happen" (Hosseini, 2018, p.32)

\section{b) Collective Trauma}

There are certain glimpses of collective trauma in this literary text Sea Prayer. The researcher has highlighted those images accordingly through the textual references.

At first, the researcher has highlighted the collective trauma that damages the communal bond between people. "I mean a blow to the basic tissue of social life that damages the bond attaching people together and impairs the prevailing sense of commonality." (Erikson, 1991)

Community or society is bound in a bond. It is a circle in which they are interacting or cooperating with each other. This very communal bond develops rules, ethics, codes and disciplines for a society to live and interact in a human manner. Likewise, bound within such a bond does not just develop a setup for society but also creates the feelings for each other. While living in such a bond; the family can be built up. However, collective trauma is considered as a threat to such a bond. This can very clearly be elaborated in this literary text Sea Prayer where the worsening political situations disintegrated the basic 
fibre of Syrian community and transformed it into the war-torn country, where everyone was pushed into the unfathomed depth of trauma. Catastrophe and forced migration are considered the main issue of the breakage of this bond. Through this text, one can evaluate the drastic impacts of war on the psyche of the community as a whole. When war broke out millions of Syrians were forced to leave the country. They started the harrowing journey with hats in hands and with the hope that others will help them. They will be compassionate towards them.

The civil war in Syria pushed it over the edge. From there it started to fall apart. The story supports the breakage of the aforementioned bond as the following instance highlights "The skies spitting bombs". (Hosseini, 2018, p.18)

This above-mentioned line in the story pictures the chaotic situation of Syria. It gives readers the image of war going on in Syria.

The word "Burials" (Hosseini, 2018, p.18) is not merely a representation of the corpses. Rather, it represents the dire consequences of the horrendous war that how it turned a peaceful country into the debris and massive graveyard. A staggering number of people lost their lives in this war.
On the other hand, half of the population was forced to leave the country. Brutal war leads the people towards displacement. They become homeless and the homes turned into debris. People got dispersed in order to stay alive. The links that they had made have now vanished.

The following instance "Your mother is here tonight, Marwan, with us, on this cold and moonlit beach..... All of us in search of home" (Hosseini, 2018, p.29) also shows the breakage of the communal bond, that war has placed people in a tight spot, where they are supposed to save their lives. They left their homes in search of safe shelter. This destroyed the communal bond within which they were living before war.

Moreover, collective trauma depicts the traumatized communities as groups that act as the collective sufferers from trauma. This can be understood from the characters of Marwan and the narrator (his father), which the writer is using as a mouthpiece for all Syrian community.

Like in the above instance, the writer has used the pronouns "us" and "we" which show the sufferings at the collective level. Marwan and his father are those characters which are the depiction of the Syrian community, the sufferings they had been through. Both show the harrowing journeys 
of Syrian refugee that how along with children they leave their homeland in search of better or safe land. For instance, "all of us in search of homes." (Hosseini, 2018, p.29)

As well as, collective demonstrates the sense of danger to the society in the form of traumatic experiences. This can be explained from the following lines of the text "We should take our misfortune elsewhere" (Hosseini, 2018, p.29). This specifies the sense of danger in the Syrian community. After migration, many countries refuse to give them asylums. So this danger remained stuck in their minds that their lives are not going to settle rather even after reaching to the safe zones they are going to suffer more and more.

In addition, at the same time, collective trauma depicts the distrust in future and mood of fear and depression. The narrator says "Pray God steers the vessel true

\section{CONCLUSION}

Lately, a trend of trauma studies is followed in literary studies. Similarly, this research study is also based on the analysis of the traumatic events in the literary text if Sea Prayer by Khaled Hosseini. Khaled Hosseini's illustrated book Sea Prayer mirrors the political commotion and ruthless war which becomes the causing factor of when the shores slip out of eyeshot and.....Easily swallowed." (Hosseini, 2018, p.38)

Above lines demonstrates the mood of fear in the refugees they carry along while their harrowing journeys. War leaves them depressed and full of fear that no matter where they are they will be depressed and fearful. By witnessing the brutality of war this usually occurs with people.

Likewise in the above lines, Marwan's father is showing readers the same effects of war. Though he has left the war-torn country still he feels fearful that something bad will happen. Marwan's father is actually a mouthpiece for whole Syrian refugee which had been through such rough times of their lives. While in an attempt to save their lives many took the risk to travel across the sea and during that voyage many of them got drowned and went missing.

trauma not only on an individual level but on a collective level as well. Sea Prayer provides the glimpses of forced migration or displacement, issues of rights deficit, impoverishment and bloodshed.

The researcher has explored the literary text of Sea Prayer by Khaled 
Hosseini in the light of Caruth (1996) personal trauma as discussed in her book Unclaimed Experience: trauma, narrative and history and Erikson (1991) collective trauma as discussed in his article Notes on Trauma and Community published in the journal. The personal trauma includes the flashbacks, timeless past, and unspeakability to comprehend one's thoughts. The same happens with the narrator (Marwan's Father) in the story, when he leaves his homeland as a result of ruthless war which destroyed his home and family. Even, during the journey towards Europe, he is getting perturbed by the flashbacks of his past how his home was turned into rubble. Though the narrator is present amongst people, travelling in search of safe destinations he is stuck in his past and can't come out. Moreover, he is not being able to verbalize his thoughts to his wife instead he says something else.

Similarly, collective trauma includes the erosion of the communal bond amongst society, traumatized communities and distrust in future and mood of depression. Khaled Hosseini used Marwan and the narrator as his representatives of the Syrian community. At one point, he seems to use pronouns such as "Us" and "We" to emphasize the community as collective sufferers of trauma. The aforementioned factors can be seen in the story when the narrator along with his wife and son, encounters many other unfortunate people, who have been displaced. In the same manner, the researcher has investigated the distrust and fear of community when the narrator expresses that they are not allowed on their safe lands and more hardships are ahead. Through this, Hosseini highlights the predicament of refugees, who get displaced from their own homelands. Also, they witnessed their houses turned into debris before their eyes. Moreover, when they arrive on others' land instead of helping, they push them away by accusing them of being terrorists. In simple words, researchers have put an attempt to throw light on such issues which leaves an indelible mark not only on the individual psyche but on collective psyches as well.

Trauma theory can provide an insight into modern literary works particularly to those which are written upon prevailing chaos in the world. Lately, most of the writings are depicting the perturbation of the world and flustered people. As well as, many books are now focusing on portraying the migrants' lives. Their trauma theory can give an in-depth analysis of those works. Trauma theory not only sheds light on the minds of people but it also recounts the drastic events 
hence highlighting the major issues of society as well.

In this research study, Sea Prayer is analyzed through the lens of trauma theory, highlighting only personal and collective trauma. However, it can also be explained through the theory of resilience and identity crisis.

\section{REFERENCES}

Abubaker, S. (2017). Art as narrative: Recounting trauma through literature. IRAInternational Journal Management and Social Sciences, Vol.08 Pg. no 118-123. https://bit.ly/2ZxEtUi

Caruth, C. (1996). Unclaimed experience: trauma, narrative and history. Baltimore: john hopkins university press.

Dodhy, S. (2017). Traumatic memory and legacy of anxiety in yvonne Vera's under the Tongue. Rupkatha Journal on Interdisciplinary Studies in Humanities.

Retrieved from https://dx.doi.org/10.21659/rupkatha.v9n1.24

Erikson, K. (1991). Note on Trauma and Community. American Imago, vol.48,pp.455 472

Emerson, R. (2007). Green Knowe An English Ark . University of Queensland Thesis. https://bit.ly/2YUZCIG

Eugene Arva, H. R. (2008). Writing trauma: magical realism and the traumatic imagination. Jnt-journal of the Narrative Theory. https://bit.ly/3ipug4N

Hosseini, K. (2018). Sea Prayer. United States: Riverhead Books.

Manshi Yadav, S. K. (2020). Analyzing delayed traumatic reactions in Stephen King's Gerald Game: A Freudian Perspective. Amity University Gurugam. https://bit.ly/2VIlSDO

Nerez, D. (2020). To Have Memories or Not - The Buried Giant Response Paper. https://bit.ly/2YVvdKn

Njovane, T. (2012). Trauma, (Mis)Perception and memory in Uwem Akpan's 'Fattening for Gabon'. English Studies in Africa, 102-112.

Retrieved from https://doi.org/10.1080/00138398.2012.731303

Onwuachi-Willig, A. (2016). "The Trauma of the Routine: Lessons of Cultural Trauma from the Emmett Till Verdict" Sociological Theory. SAGE Journals, 335-357.

Retrieved from https://doi.org/10.1177/0735275116679864

Samia Hanif, I. (2108). WarTrauma, Collective Memory,and Cultural Productions in Conflict Zones: Kashmir in Focus. SAGE journals. Retrieved from https://doi.org/10.1177/2158244018800912 